\title{
Commentary
}

\section{The Other Mobile TV: ATSC MDTV Broadcasting In Canada}

\author{
Steven James May \\ Ryerson and York Universities \\ Catherine Middleton \\ Ryerson University
}

\begin{abstract}
This commentary describes an approach for delivering television content to mobile phones in Canada using over-the-air broadcast signals. Over-the-air television broadcasting to mobile phones is available to our American neighbours but has not been implemented in Canada. We report on a test of mobile TV services, demonstrating access to U.S. signals from Canada. While it is technically feasible to deliver over-the-air mobile broadcasting in Canada, it is likely that vertical integration in the broadcasting and communications sectors is creating barriers to the development of this service. The commentary concludes with some thoughts on how mobile digital television services could be developed for Canadian viewers.
\end{abstract}

\section{KEYWORDS Communication; Television; Mobile}

RÉSUMÉ Ce commentaire décrit une approche qui consisterait à diffuser en ondes ici au Canada un contenu télévisuel destiné aux téléphones mobiles. Nos voisins américains, contrairement à nous, ont la capacité de recevoir des émissions de télévision sur leurs téléphones mobiles. Dans cet article, nous présentons un test démontrant que les Canadiens peuvent eux aussi accéder aux signaux américains. Bien qu'il soit techniquement possible d'offrir ce type de service au Canada, il est probable que l'intégration verticale des secteurs de radiodiffusion et de communication soit une entrave à son développement. Pour conclure, ce commentaire offre quelques réflexions sur la manière dont on pourrait développer un tel service pour un public canadien.

MOTS CLÉS Communication; Télévision; Mobile

\section{ATSC MDTV primer}

$\mathrm{n}$ August 31, 2011, Canadian television broadcasters (with the exception of the
Canadian Broadcasting Corporation) were required by the Canadian Radio-televi-

Steven James May is a $\mathrm{PhD}$ candidate in Communication \& Culture at Ryerson and York Universities. Email: steven.may@ryerson.ca.Catherine Middleton is Research Chair, Communication Technologies in the Information Society and Professor, Ted Rogers School of Information Technology Management, Ryerson University. Email: catherine.middleton@ryerson.ca .

Canadian Journal of Communication Vol 38 (2013) 663-672

(C)2013 Canadian Journal of Communication Corporation 
sion and Telecommunications Commission (CRTC) to cease analog over-the-air (OTA) television broadcasting in mandatory digital markets (Canadian Radio-television and Telecommunications Commission, 2010). Broadcasters that wanted to continue broadcasting in such markets (which include the National Capital Region, provincial capitals and other markets with populations greater than 300,000) beyond the 2011 analog shutoff date were required to upgrade their transmitters to the Advanced Television Systems Committee (ATSC) digital television (DTV) standard. As for the Canadian Broadcasting Corporation (CBC/Radio Canada), it opted to end all analog television broadcasting as of July, 2012. The Government of Canada did not provide broadcasters with funding or other incentives to make the transition to digital television.

With ATSC digital television transmitters now operational in many Canadian television markets, broadcasters have an opportunity to deliver over-the-air signals to mobile devices. Since ATSC digital television signals are configured for delivery to stationary devices only, broadcasting to mobile devices requires use of the ATSC Mobile Digital Television standard, known as MDTV or M/H (Mobile/Handset). Once converted to the ATSC MDTV standard, television signals can then be received by MDTV devices travelling at speeds in excess of $160 \mathrm{~km} / \mathrm{h}$ (Innovative DTV Solutions, Inc., 2010). In terms of the additional equipment needed by broadcasters in order to send out MDTV signals, a representative of the Open Mobile Video Coalition (OMVC) advised us that once ATSC digital transmitters become operational, it only takes "a few hours" and \$100,000 (USD) per station to upgrade digital transmitters to allow for simultaneous ATSC MDTV broadcasting (personal communication, July 29, 2011). However, as of early 2013, there are no Canadian stations broadcasting regularly scheduled programming using MDTV signals.

\section{Why not Canada?}

A Canadian broadcaster with whom we spoke blames a "chicken or the egg" scenario for the lack of ATSC MDTV broadcasting in Canada (personal communication, July 29, 2011). This explanation suggests Canadian television broadcasters are first waiting for MDTV-enabled devices to be made available to the public before sending out MDTV signals and that mobile device manufacturers are waiting for television broadcasters to start sending MDTV signals before offering MDTV-enabled devices to the public.

A possible solution to this impasse would be for Canadian television broadcasters to simply work together towards MDTV penetration in Canada. Such an approach was leveraged in the United States under the OMVC prior to the 2009 digital television transition in that country (OMVC, 2008b). Early efforts by American television broadcasters operating under the OMVC to promote mobile television featured MDTV testing in Washington, D.C. and required cooperation with device manufacturer Samsung and wireless service provider Sprint (Ankeny, 2010). As of 2012, a reported 120 television stations were broadcasting MDTV signals in the United States (Mann, 2012). Most recently, a new MDTV subscription-based service named Dyle mobile TV was launched in August, 2012 (MetroPCS Communications, Inc., 2012). Dyle mobile TV is offering its content to subscribers for no fee until the end of 2013 (Mobile Content Venture, LLC, 2012).

Why have similar MDTV initiatives not come to fruition in Canada? Steen (2009) articulates four factors that contribute to mobile television uptake. These may account for the absence of MDTV in Canada, moving beyond the argument that the problem is 
simply a lack of cooperation among broadcasters, mobile device manufacturers, and mobile service providers. Steen argues that 1) users must be willing to pay for the service; 2) there needs "to be licensed and available content that these consumers are interested in watching" (Steen, 2009, p. 325); 3 ) devices that can receive the content are required; and, 4) the infrastructure to send out the signals to mobile devices must be in place. We use these four factors as a guide to analyze the lack of ATSC MDTV in Canada.

\section{Willingness to pay for mobile TV service in Canada}

Canada's major mobile phone carriers all offer a mobile TV service. Pricing models and availability of content differ by carrier, but all services are offered using the carriers' cellular data networks and not by MDTV. In this commentary, we explore issues of mobile TV uptake using Bell Mobility as an example. 7.8 million Canadians subscribe to Bell Mobility's services and its parent company, Bell, is "Canada's largest communications company" (BCE, 2012, p. 23). Through Bell Media, Bell owns television network CTV. Bell is not unique in owning a mobile carrier and a television broadcaster but we focus on Bell because of its ownership of Canada's "most-watched" television network, CTV (Bell Media, 2013).

Bell's mobile television service, dubbed Bell Mobile TV, requires customers to subscribe to a Bell data plan and pay a $\$ 5$ per month premium to receive 10 hours of mobile television (Bell, 2013). If a customer watches more than 10 hours of mobile television in a single month they are billed $\$ 3$ for each additional hour of mobile television viewed. Such a billing structure means that it would currently cost a Bell Mobile TV subscriber about $\$ 150$ per month or $\$ 1,800$ per year (plus applicable taxes) to watch two hours of Bell Mobile TV per day. ${ }^{1}$

While diehard sports fans and other keen mobile television viewers may be willing and able to pay mobile TV user fees to watch live sporting events on their mobile devices, a niche customer base is unlikely to be enough to sustain a robust mobile television market in Canada. Alternatively, if CTV were to offer MDTV broadcasts of live sports in their digital television markets, viewers with MDTV devices in those markets could watch the games for no additional fees. This would be possible by extending the existing advertising-supported model of broadcasting to mobile broadcasting, and would require upgrading digital transmitters to support MDTV. In terms of what the broadest possible television audience would be willing to pay for access to Figure Skating or the National Football League (NFL) on mobile devices, the ad-supported MDTV broadcast distribution model provides an attractive alternative for mobile device users in comparison to the hourly pricing model currently offered by mobile carriers.

\section{Availability of content}

Bell Mobile TV subscribers have access to television programming via Bell-owned conventional television broadcasters CTV and CTV Two, in addition to non-Bell television channels. Similar to other Canadian private television broadcasters, CTV and CTV Two fill a significant portion of their programming schedules with popular American dramas. This programming is also being leveraged to help promote Bell Mobile TV.

If Bell were to provide over-the-air MDTV broadcasts of the same American television content aired on its CTV and CTV Two channels, instead of requiring viewers 
to subscribe to Bell Mobile TV, greater mobile audience numbers are feasible in digital over-the-air markets. Bell Mobile TV's paid subscriber model for the mobile delivery of CTV and CTV Two programming could act as a barrier to securing significant mobile television viewer ratings when compared to barrier-free access to over-the-air MDTV signals.

As for Canadian television programming on CTV and CTV Two, MDTV broadcasting could also provide an opportunity to distribute targeted local news to viewers. Bell Mobile TV does not provide many local television viewing options. While Bell does provide access to CTV's main network through Bell Mobile TV, it does not for example provide local CTV Ottawa (CJOH) or CTV Kitchener (CKCO) newscast options (personal communication, May 31, 2013). In comparison, if CTV were to offer MDTV versions of their over-the-air Ottawa and Kitchener suppertime news broadcasts, viewers in those communities would have access to such local broadcasts while travelling outside of the home. This would also provide a broader reach for local businesses paying for ads on local CTV Ottawa or CTV Kitchener broadcasts. Television commercials featuring hyper-local products and services would not only reach CTV viewers watching at home but would also reach members of the community watching on MDTV-enabled mobile devices.

In addition, a unique selling feature of MDTV is the usefulness of over-the-air television broadcasting during emergencies. Unlike Internet and cellular telephone networks that often go down during emergency and disaster scenarios, the over-the-air broadcasting model (one-to-many instead of one-to-one) is robust and able to maintain the delivery of information to the public during emergencies (OMVC, 2008a). This feature of ATSC DTV and ATSC MDTV is appreciated in the United States following September 11, 2001, and is promoted to the American public based on such merits. While the safety and security aspect of MDTV has not been embraced in the same fashion in Canada, it would make for a valuable content delivery method during extreme weather events.

\section{Availability of receivers}

As of early 2013, no mobile devices capable of receiving MDTV signals are available for sale within Canada. MDTV devices are not offered by Canadian wireless service providers or by electronics stores located in Canada. This lack of MDTV products available for purchase in Canada is a clear barrier to MDTV uptake in the country. How can interest in MDTV services in Canada be gauged if MDTV devices are not made available on even a test-market basis?

The only way for someone in Canada to experience MDTV is to purchase a MDTV device from a retailer in the United States and attempt to pick up MDTV signals in border communities. In order to evaluate the potential merits of MDTV broadcasting in Canada, we bought a "RCA 3.5" Mobile DTV/ATSC Hybrid Pocket Digital TV, which is able to receive both ATSC DTV and MDTV signals via its built-in telescoping antenna.

While the MDTV setting on such a device is currently of little use to most residents of Canada, it is a different story for the residents of Windsor, $\mathrm{ON}$, and the surrounding area. MDTV signals broadcast from Detroit, MI, easily make their way across the border into Southern Ontario. Similar to American DTV signals, American MDTV signals can 
be accessed outside the U.S. Provided viewers have an MDTV enabled device and are within the MDTV signal footprint, they are able to enjoy freely available over-the-air MDTV content on their MDTV enabled device.

Figure 1: MDTV signal reception testing in Windsor, Ontario

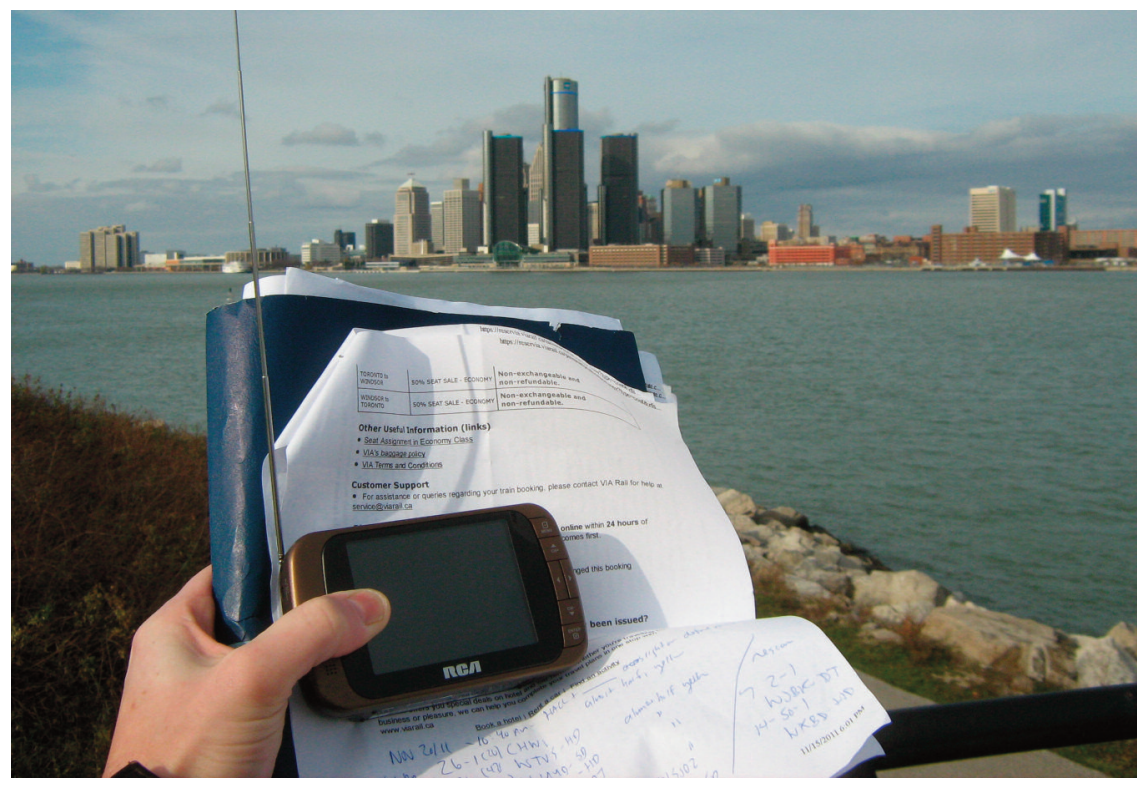

Source: Steven James May

During a November, 2011, research trip to Windsor, ON, MDTV broadcasts originating from WXYZ, ABC Detroit, and WDIV (an NBC affiliate also out of Detroit), were received on the RCA mobile television (Figure 1). Both signals utilized H. 264 video compression and the signal from WDIV indicated that Closed Captioning was available. No Canadian MDTV signals were received on the device.

While it was expected that some MDTV signals would be received by the RCA unit when physically standing on the Canadian banks of the Detroit River, high speed testing on a Via Rail passenger train revealed the most exciting data from the MDTV research trip. Departing eastbound from Windsor, a Golf Channel live broadcast of the 2011 Presidents Cup was received on the RCA device care of WDIV's MDTV broadcast.

The RCA MDTV unit held the live golf broadcast as the train pulled out of the Windsor station and maintained a clear connection with the WDIV transmitter as the train accelerated toward Toronto. Only once the train pulled into Chatham, 80 kilometers east of Detroit, did the RCA device lose reception of the broadcast.

This research trip illustrated the type of mobile setting where a device like the RCA Hybrid DTV/MDTV would be of use to passengers commuting by train or automobile near Windsor, ON. A similar regularly scheduled MDTV broadcast service by a Canadian broadcaster in the Greater Toronto Area would be an attractive option for 
Figure 2: Viewing a MDTV broadcast on a moving train

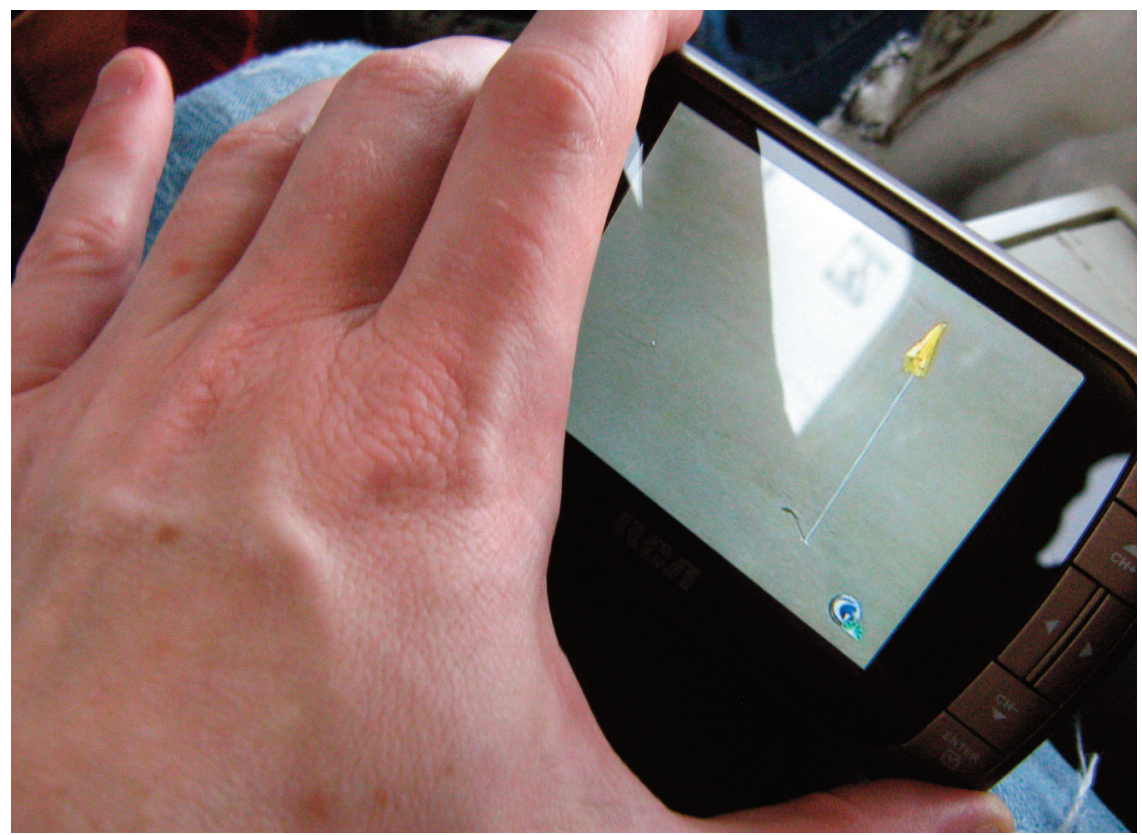

Source: Steven James May

Canadians seeking local and live television while travelling to and from their places of employment or schooling.

\section{ATSC transmitter infrastructure}

As required by the CRTC, all Canadian broadcasters other than CBC/Radio-Canada switched their television transmitters to digital in mandatory markets as of August 31, 2011. As such, urban centres across Canada, including Vancouver, Calgary, Winnipeg, Toronto, Ottawa, Montreal, and Halifax, are now served by ATSC digital transmitters. Additional non-mandatory digital markets may also be upgraded to digital television broadcasting in the years to come. While there would be additional nominal costs for broadcasters operating in digital markets to upgrade to MDTV, the hard part of installing the main digital transmitter and doing the cutover from analog to digital is now complete for broadcasters in mandatory digital markets.

While it would seem to make sense for digital television broadcasters to make the upgrade to MDTV, Canada is without regular MDTV broadcasting more than two years after Canada's digital television transition. When asked about the state of MDTV broadcasting in Canada, one Canadian broadcast executive notes that "with no receivers in the market, there is no case for broadcasting yet," admitting, however, that "the modifications that would be required (for MDTV broadcasting) to our HD transmitters are relatively minor" (personal communication, July 16, 2011).

When we asked a representative of a major device manufacturer about the status of MDTV device availability in Canada, the response also referenced the chicken or 
egg scenario but in reverse. Blaming lack of signals for the lack of MDTV enabled mobile devices in Canada, this individual advised that "licensing for mobile is a trick here" since mobile service providers like Bell, Rogers, and Telus want "phones that support their services" (emphasis in original). This individual noted the device manufacturer "would be more than happy to sell these [MDTV enabled] devices here [Canada]" (personal communication, June 1, 2012).

Beyond the mobile device issue - which could easily be resolved by Canadians purchasing desired devices online (just as they did in 2007 when Apple's iPhone was not for sale within Canada) - another reason why CTV and CTV Two have not moved forward with MDTV broadcasting on a regular basis is likely linked in part to their current owners. In September, 2010, Bell parent BCE Inc. announced that it was increasing its ownership of CTV, becoming the full owner of Canada's largest private broadcaster. Within six months of the announcement, Bell had launched its Bell Mobile TV subscription service. While CTV reportedly conducted limited MDTV testing in Kitchener, ON, in June, 2012, "at the request of some high tech firms in the region" (Digital Home, 2012), Bell's approach and promotion of mobile television since acquiring full ownership of CTV has been focused on its cellular Bell Mobile TV service. As Canada's largest private broadcaster, CTV's ongoing involvement with MDTV would have greatly nurtured MDTV development in the country. Following Bell's full ownership stake in CTV, this opportunity has significantly faded.

\section{National digital broadcasting policy in Canada}

In addition to Steen's list of four factors that contribute to mobile television uptake, a fifth factor of national digital broadcasting policy is also relevant to Canada's MDTV broadcasting story. Member of Parliament and New Democrat Party (NDP) digital policy critic Charlie Angus noted at a 2011 Canadian Heritage Committee meeting, that Canada's digital television transition had been a "hodgepodge" policy effort (Angus, 2011). The end result of Canada's approach to the digital television transition is a current television broadcast environment where major urban centres are now fully digital in terms of over-the-air television broadcast offerings, while the rest of Canada is either still receiving analog over-the-air television or is without any over-the-air television signals whatsoever. ${ }^{2}$

Any future MDTV penetration in Canada, via Canadian television broadcasters, will depend on this patchwork of urban DTV transmitters installed across the country. Citizens who live in large Canadian cities and currently have access to DTV signals could stand to benefit from MDTV broadcasting. Those living outside digital over-theair markets would not be as well served by MDTV until local DTV transmitters become operational. Canada's existing DTV transmitter patchwork also does not provide the potential for roaming MDTV in Canada, on trains or otherwise, again due to the scattered placement of digital television transmitters in Canada.

\section{Barriers to MDTV in Canada}

The discussion above notes that some Canadians are willing to pay for mobile television services, but also makes the point that if mobile TV were to be broadcast over-the-air, the service could be freely accessed on MDTV-enabled devices. Such devices are avail- 
able outside Canada, and could be made available to Canadian consumers. Television content is currently broadcast over-the-air in major cities in Canada (the mandatory markets for digital television), but the infrastructure to make these broadcast signals available to mobile devices in not in place. Thus, of Steen's four factors needed to encourage mobile TV uptake, the primary barrier is the lack of ATSC transmitter infrastructure in Canada. Although devices are not currently available in Canada, we argue that if mobile digital TV signals were to become available, the devices would follow.

From a technical perspective, the barriers to implementation of MDTV in Canada are surmountable. It is likely however that the vertical integration of Canada's telecommunications and broadcasting industries is constraining MDTV development in the country. The nesting approach that the CRTC has taken in terms of permitting large Broadcast Distribution Undertakings (BDUs) to purchase private Canadian television broadcasters has largely eliminated the distinction between national television broadcasters and BDUs in Canada. There is now little incentive for BDUs to invest in MDTV when DTV broadcasting is hampered by a patchwork of operational digital transmitters. Further, providing an opportunity for existing mobile television subscribers to shift from a paid subscription model to over-the-air distribution would cannibalize revenues earned by mobile phone companies for providing mobile television services.

\section{Potential champions of MDTV in Canada}

With the apparent disinterest in MDTV expressed by privately-owned BDUs, Canada's national public broadcaster, the Canadian Broadcasting Corporation (CBC/RadioCanada), is well positioned to take a leadership role in Canadian MDTV broadcasting. $\mathrm{CBC}$ /Radio-Canada has been conducting MDTV testing in Canada since 2009 and has test broadcast MDTV sub-channels of CBC Television in Toronto, ON, and Montréal, QC (Aubé, 2013). While the public broadcaster has been forced in recent years to adjust its spending in light of cuts to its annual Federal appropriation funds, it is arguable that $\mathrm{CBC}$ /Radio-Canada as the national public broadcaster has an obligation under the Broadcasting Act to attempt national MDTV broadcasting in a meaningful way. CBC/Radio-Canada's decision to rely on 27 digital television transmitters to distribute its digital over-the-air signals across all of Canada does present a coverage challenge for MDTV. However, key television markets such as Toronto, Montreal, Halifax, and Vancouver that are currently served by digital over-the-air transmitters do provide an excellent opportunity for $\mathrm{CBC} /$ Radio-Canada to further explore the potential benefits of MDTV to Canadians.

In addition to CBC/Radio-Canada, independently-owned private television broadcasters such as $\mathrm{CHCH}$ and CHEK are also well positioned to take a leadership role in MDTV broadcasting within Canada. With $\mathrm{CHCH}$ serving the Greater Toronto Area from their base in Hamilton, ON, and CHEK serving the Vancouver area from their base in Victoria, BC, CHCH's and CHEK's embracing of MDTV broadcasting could make great strides towards the promotion of service in two of Canada's largest metropolitan areas.

As for the lack of MDTV devices available in Canada, mobile device manufacturer BlackBerry could seize MDTV as a way for the Canadian company to help reinvigorate its brand. By including MDTV chips in their mobile phones and tablets in Canada as 
a test market, BlackBerry could use the mobile television knowledge gained in this country to compete with competitors such as Apple, Samsung, Microsoft, and Google in the U.S. and elsewhere. However, since BlackBerry sells its mobile phones in Canada through Canadian mobile carriers, it is possible that carriers would resist this move and request that BlackBerry devices not be MDTV-enabled in Canada.

\section{Need for a MDTV Plan}

It is unlikely that BDUs will be leading the MDTV charge in Canada. However, a mutually beneficial arrangement between $\mathrm{CBC}$ /Radio-Canada, independent private television broadcasters such as $\mathrm{CHCH}$ and $\mathrm{CHEK}$, and a device manufacturer like BlackBerry could help bring MDTV to Canadians. A Canadian version of the OMVC, which has already made great strides in MDTV penetration in the United States, would help bring about the required factors for mobile television uptake. Otherwise, Canadian access to mobile television will continue to be tied to, and potentially restricted by, subscription-based cellular networks and metered data plan rates.

This commentary offers some insights on developing mobile digital television services in Canada. Our primary objective was to raise awareness of the possibility of using over-the-air signals to make mobile TV services available to Canadians. The barriers to such services do not appear to be technical, but rather seem to be a result of Canada's vertically integrated broadcasting and communications environment. This commentary provides a starting point for further investigation into the possibilities of greatly expanded mobile television access for Canadians.

\section{Notes}

1. Pricing information sourced from http://tvanywhere.bell.ca/en/pricing and accurate as of November, 2013.

2. For a comprehensive overview of Canada's digital television transition, see Taylor (2013).

\section{References}

Angus, C. (2011, March 2). Canadian heritage committee on March 2nd, 2011. URL: http://openparliament .ca/committees/canadian-heritage/40-3/44/charlie-angus-2/ [February 3, 2013].

Ankeny, J. (2010, January 6). Sprint and Samsung to launch free mobile DTV trial. URL: http://www fiercemobilecontent.com/story/sprint-and-samsung-launch-free-mobile-dtv-trial/2010-01-06 [February 3, 2013].

Aubé, Philippe. (2013). Mobile digital television (ATSC M/H): Field-testing \& measurements. CBC Radio-Canada. SYNC 3. http://www.cbc.radio-canada.ca/en/reporting-to-canadians/sync /sync-issue-3-2013/mobile-digital-television [November, 2013].

BCE. (2011). Bell Mobility announces enhanced Mobile TV service featuring live and on-demand access to the leading names in Canadian media. URL: http://www.bce.ca/news-and-media/releases/show/2011-04-04-2011-04-04-2011-04-04-bell-mobility-announces-enhanced-mobiletv-service-featuring-live-and-on-demand-access-to-the-leading-names-in-canadian-media [January 7, 2013].

BCE. (2012). 2012 Annual Report. URL: http://www.bce.ca/assets/investors/AR-2012/BCE_2012 _AnnualReport_accessible.pdf.[June 5, 2013].

Bell. (2013). Mobile TV add-on. URL: http://www.bell.ca/Mobility/Products/Mobile_TV [January 7, 2013].

Bell Media. (2013). About us. URL: http://www.bellmedia.ca/about/Media_Landing.page\#tabCont 4 -tabs [January 18, 2013]. 
Canadian Radio-television and Telecommunications Commission (CRTC). (2010). Broadcasting information bulletin CRTC 2010-719. URL: http://www.crtc.gc.ca/eng/archive/2010/2010719.htm [January 7, 2013].

Digital Home. (2012). Status of ATSC-MH (mobile) stations in Canada: Post \#34. URL: http://www .digitalhome.ca/forum/showthread.php?s = ecacec61be227cd54754b8fec3bacee5\&t $=154600$ \&page $=3$ [February 3, 2013].

Hardy, I. (2012, August 17). Bell increasing Mobile TV overage rates August 21st, impacts new customers only. URL: http://mobilesyrup.com/2012/08/17/bell-increasing-mobile-tv-overagerates-august-21st-impacts-new-customers-only/ [January 7, 2013].

Innovative DTV Solutions, Inc. (2010). ATSC Mobile DTV Standard. URL:http://www.rcamobiledigitaltv.com/ [February 3, 2013].

Mann, C. (2012, January 9). 120 US mobile digital TV stations. URL: http://advanced-television .com/2012/01/o9/120-us-mobile-digital-tv-stations/ [February 4, 2013].

MetroPCS Communications, Inc. (2012, August 3). MetroPCS dials in unique entertainment experience with the Samsung Galaxy S Lightray 4G smartphone. URL: http://www.prnewswire.com /news-releases/metropcs-dials-in-unique-entertainment-experience-with-the-samsunggalaxy-s-lightray-4g-smartphone-164868166.html [February 3, 2013].

Mobile Content Venture, LLC. (2012). FAQs. URL: http://www.dyle.tv/faqs/ [February 3, 2013].

Open Mobile Video Coalition (OMVC). (2008a). About OMCV. URL: http://web.archive.org /web/20120418080650/http://www.omvc.org/about-omvc/ [February 4, 2013].

OMVC. (2008b). ATSC mobile DTV standard. URL: http://web.archive.org/web/20120718125003 /http://www.omvc.org/about-mobile-dtv/standards [February 4, 2013].

OMVC. (2012, April 13). Broadcasters Gear Up for 2012 Commercial Mobile DTV [Press release]. URL: http://www.globenewswire.com/news-release/2012/o4/17/473450/252309/en /Broadcasters-Gear-Up-for-2012-Commercial-Mobile-DTV.html [February 3, 2013].

Steen, H.U. (2009). Technology convergence, market divergence: Fragmentation of standards in mobile digital broadcasting carriers. Information Systems and E-Business Management, 7(3), 319-345.

Taylor, Gregory. (2013). Shut-off: The Canadian digital television transition. Montreal, QC: McGill-Queen's University Press. 